AKRUAL 3 (2) (2012): 147-166 e-ISSN: 2502-6380

AKRUAL

Jurnal Akuntansi

http://fe.unesa.ac.id/ojs/index.php/akrl

\title{
PENGARUH INFLASI, SUKU BUNGA, NILAI TUKAR VALAS DAN JUMLAH UANG BEREDAR TERHADAP PROFITABILITAS PADA PERBANKAN SYARIAH DI INDONESIA PERIODE 2005-2009
}

\author{
Desi Marilin Swandayani \\ Rohmawati Kusumaningtias \\ Fakultas Ekonomi Universitas Negeri Surabaya \\ E-mail: rohmawatikustia@yahoo.co.id \\ Artikel diterima: 16 November 2011 \\ Terakhir direvisi: 3 Januari 2012
}

\begin{abstract}
Islamic finance quality show that performance improved, as indicated by the growing share of financing for the results of mudharabah and musyarakah. This study was conducted to examine the effect of macro economic indicators as measured by inflation, interest rates, foreign currency exchange rates and money supply to the ROA of Islamic Banking in Indonesia. Data analysis techniques used in this study is multiple linear regression analysis. $F$ test results showed that simultaneous independent variables affect ROA. While the results of $t$ tests showed that the inflation variable showed no significant effect on ROA. This is because, when inflation is high then the public more confidence in the Islamic banking compared with conventional banking. Predictive ability of four variables on ROA in this study by $19.8 \%$, while the remaining $80.2 \%$ influenced by other factors that are not included in the research model.
\end{abstract}

Keywords: Return On Assets, Inflation, Interest Rates, Foreign Exchange Rates, Money Supply

\section{PENDAHULUAN}

\section{Latar Belakang}

Peranan sistem finansial yang didominasi oleh perbankan tampak dari dana yang dihimpun dan yang digunakan untuk membiayai kegiatan pembangunan, khususnya di sektor swasta sebagian besar masih berasal dari sektor perbankan. Sektor perbankan merupakan sektor yang sangat penting peranannya di dalam pembangunan nasional baik sebagai perantara sektor yang defisit dengan sektor yang surplus maupun sebagai agen pembangunan (Marieskha, 2009).

Perkembangan perbankan syariah di Indonesia telah menjadi tolak ukur keberhasilan eksistensi ekonomi syariah. Krisis moneter yang terjadi pada tahun 1998 telah menenggelamkan bank-bank konvensional dan banyak yang dilikuidasi karena 
kegagalan sistem bunganya. Sementara perbankan yang menerapkan sistem syariah dapat tetap berdiri dan mampu bertahan. Hal ini dapat dibuktikan dari keberhasilan bank Muamalat Indonesia melewati krisis yang terjadi pada tahun 1998 dengan menunjukkan kinerja yang semakin meningkat dan tidak menerima sama sekali bantuan dari pemerintah bahkan mampu memperoleh laba Rp. 300 milliar lebih. Tidak hanya itu, pada saat krisis keuangan global pada tahun 2008, bank syariah kembali membuktikan daya tahannya dari krisis. Bank syariah tetap stabil dan memberikan keuntungan, kenyamanan serta keamanan bagi para pemegang sahamnya, pemegang surat berharga, peminjam dan para penyimpan dana (Statistik Perbankan Syariah, BI:2011).

Seiring dengan diberlakukannya dual banking system oleh Undang-Undang Nomor 10 Tahun 1998 tentang Perbankan telah memberikan kontribusi besar dalam percepatan pertumbuhan perbankan syariah. Sebagai tindak lanjut dari ketentuan yang ditetapkan bagi perbankan syariah, pemerintah juga mengeluarkan Peraturan Bank Indonesia No.11/3/PBI/2009 tentang Bank Umum Syariah. Dan Peraturan Bank Indonesia No.11/10/PBI/2009 tentang Unit Usaha Syariah. Serta Peraturan Bank Indonesia No.11/15/PBI/2009 tanggal 29 April 2009 tentang Perubahan Kegiatan Usaha Bank Konvensional menjadi Bank Syariah.

Selain itu, dikeluarkannya Fatwa MUI pada tanggal 16 November 2003 yang menjelaskan bahwa bunga bank adalah riba dan berstatus haram telah memberikan harapan besar bagi perkembangan perbankan syariah. Kualitas pembiayaan syariah menunjukkan kinerja yang membaik yang ditandai dengan membesarnya porsi pembiayaan bagi hasil yaitu mudharabah dan musyarakah. Hingga akhir kuartal pertama tahun 2005, pembiayaan syariah mencapai lebih dari 16 triliun. Selain itu, Undang-Undang No.21 Tahun 2008 tentang Perbankan Syariah merupakan angin segar bagi industri perbankan syariah. Sejak berlakunya undang-undang tersebut jaringan kantor perbankan syariah berkembang sangat pesat. Data dari Bank Indonesia menunjukkan bahwa total kantor bank syariah yang semula 597 kantor pada tahun 2007 sudah mencapai 822 kantor pada tahun 2008. Pada Grafik 1.1 terlihat juga aset, dana pihak ketiga, pembiayaan yang diberikan bank syariah mengalami tren menaik.

Perbankan syariah mengalami kinerja yang relatif lebih baik dibandingkan perbankan konvensional. Hal ini dapat dilihat dari relatif rendahnya penyaluran pembiayaan yang bermasalah (Non Performing Financings) pada perbankan syariah dibandingkan dengan pembiayaan yang bermasalah (Non Performing Loan) perbankan konvensional.

Tabel 1. NPL dan NPF Perbankan di Indonesia Tahun 2005-2009

\begin{tabular}{lccccc}
\hline & $\mathbf{2 0 0 5}$ & $\mathbf{2 0 0 6}$ & $\mathbf{2 0 0 7}$ & $\mathbf{2 0 0 8}$ & $\mathbf{2 0 0 9}$ \\
\hline NPL Perbankan Konvensional & $7.56 \%$ & $6.07 \%$ & $4.07 \%$ & $3.20 \%$ & $3.31 \%$ \\
NPF Perbankan Syariah & $2.82 \%$ & $4.75 \%$ & $4.05 \%$ & $3.95 \%$ & $4.01 \%$ \\
\hline
\end{tabular}

Sumber : Bank Indonesia (2009) 
Sebagai lembaga yang penting dalam perekonomian maka perlu adanya pengawasan kinerja yang baik oleh regulator perbankan. Salah satu indikator untuk menilai kinerja keuangan suatu bank adalah melihat tingkat profitabilitasnya. Profitabilitas merupakan indikator yang paling tepat untuk mengukur kinerja suatu bank (Hasibuan, 2005:100). Profitabilitas adalah kemampuan bank dalam menghasilkan laba. Laba merupakan hal yang penting bagi bank karena di dalam laba tercermin tingkat kepercayaan masyarakat kepada bank, sebagai tolok ukur tingkat kesehatan bank, tolok ukur baik buruknya manajemen bank, dapat meningkatkan daya saing dan status bank. Berdasarkan Surat Edaran Bank Indonesia No.6/23/DPNP tanggal 31 Mei 2004 tentang Sistem Penilaian Tingkat Kesehatan Bank Umum, terdapat delapan indikator yang digunakan untuk mengukur tingkat profitabilitas, yaitu return on asset, return on equity, net interest margin, biaya operasional dibandingkan dengan pendapatan operasional, perkembangan laba operasional, komposisi portofolio aktiva produktif dan diversifikasi pendapatan, penerapan prinsip akuntansi dalam pengakuan pendapatan, prospek laba operasional.

Dalam penelitian ini yang akan digunakan sebagai indikator profitabilitas adalah ROA. Penggunaan ROA ini didasarkan atas penelitian terdahulu oleh Setiawan (2009) dan Rosanna (2007). Penelitian tersebut menggunakan ROA untuk mengukur profitabilitas bank. Menurut Setiawan (2009), ROA penting bagi bank karena Bank Indonesia lebih mengutamakan nilai profitabilitas suatu bank yang diukur dengan asset yang dananya sebagian besar berasal dari dana simpanan masyarakat. Van Horne (2002:361) juga mengemukakan bahwa rasio yang digunakan umumnya dalam mengukur tingkat profitabilitas adalah ROA. Di samping itu, ROA merupakan metode pengukuran yang paling obyektif yang didasarkan pada data akuntansi yang tersedia dan besarnya ROA dapat mencerminkan hasil dari serangkaian kebijakan perusahaan terutama perbankan. ROA merupakan ukuran dari kinerja keuangan bank dalam memperoleh laba sebelum pajak, yang dihasilkan dari total asset (total aktiva) bank yang bersangkutan (Surat Edaran BI No.3/30/DPNP tanggal 14 Desember 2001). Semakin besar ROA menunjukkan kinerja bank semakin baik, karena tingkat pengembalian (return) semakin besar (Husnan, 1992:215).

Dalam pelaksanaan kegiatan operasionalnya, bank tidak terlepas dari pengaruh kondisi perekonomian. Kaitannya dalam hal ini, faktor-faktor ekonomi makro seperti neraca pembayaran, pendapatan nasional meliputi produk domestik bruto dan produk nasional bruto, gross domestik produk, tingkat pertumbuhan ekonomi, tingkat inflasi, tingkat pengangguran, nilai tukar valas, jumlah uang beredar dan suku bunga (Sukirno, 2006:26). Dalam penelitian ini digunakan indikator ekonomi makro, seperti inflasi yang ditunjukkan dalam indeks harga konsumen, suku bunga yang diwakili oleh suku bunga SBI selama 1 bulan, nilai tukar valas yang ditunjukkan dalam kurs tengah US\$, serta jumlah uang beredar dalam arti luas atau M2. Pemilihan indikator ekonomi makro ini didasarkan atas penelitian terdahulu oleh Rosanna (2007) dan Perdana (2009).

Sebagai lembaga intermediasi, bank sangat rentan dengan risiko inflasi terkait dengan mobilitas dananya. Apabila suatu negara mengalami inflasi yang tinggi akan 
menyebabkan naiknya konsumsi, sehingga akan mempengaruhi pola saving dan pembiayaan pada masyarakat. Perubahan tersebut akan berdampak pada kegiatan operasional bank syariah, jumlah dana dari masyarakat yang dihimpun akan semakin berkurang sehingga nantinya akan mempengaruhi kinerja bank syariah dalam memperoleh pendapatan dan menghasilkan profit (Sukirno, 2006:15). Teori di atas didukung oleh penelitian Hassan dan Bashir (2002) yang melakukan penelitian pada bank syariah. Dalam penelitiannya, Hassan menggunakan 231 sampel bank syariah dari 21 negara untuk periode 1994-2001. Hassan menjelaskan bahwa inflasi mempunyai pengaruh signifikan terhadap profitabilitas bank syariah. Selain itu, penelitian oleh Vong dan Chan (2008) juga mengatakan bahwa inflasi berpengaruh signifikan terhadap profitabilitas pada bank umum di Macau.

Tetapi teori dan penelitian di atas bertolak belakang dengan penelitian yang dilakukan oleh Kunt dan Huizinga pada tahun 2001 dengan menggunakan sampel bank umum. Kunt menjelaskan bahwa inflasi justru tidak berpengaruh terhadap profitabilitas bank, dengan syarat bank mampu menaikkan tingkat bunganya lebih cepat dari pada biaya yang timbul akibat inflasi. Selain itu, Aburime pada tahun 2005 juga melakukan penelitian tentang pengaruh indikator ekonomi makro terhadap profitabilitas bank di Nigeria. Dalam penelitiannya juga mengatakan bahwa inflasi tidak mempunyai pengaruh terhadap profitabilitas bank umum di Nigeria.

Selain inflasi, variabel lain yang berpengaruh terhadap profitabilitas bank adalah suku bunga Sertifikat Bank Indonesia. Dalam menentukan tingkat bagi hasil baik dalam pendanaan maupun pembiayaan, bank syariah masih mengacu kepada tingkat suku bunga umum sebagai equivalent rate atau masih dijadikan benchmark dalam penentuan margin bagi hasil (profit sharing). Meningkatnya suku bunga pada bank konvensional mengakibatkan nasabah akan memindahkan dananya ke bank konvensional. Naiknya suku bunga bank konvensional berakibat langsung terhadap sumber dana pihak ketiga bank syariah. Penurunan DPK pada bank syariah akibat pemindahan dana tersebut tentunya sangat mempengaruhi kegiatan operasional bank syariah dalam hal pembiayaan dan penyaluran dana. Bila hal tersebut terjadi, maka pendapatan dan profit bank akan menurun (Karim, 2002). Hasil penelitian Rosanna (2007) menyatakan bahwa suku bunga SBI berpengaruh signifikan terhadap profitabilitas. Sedangkan, hasil penelitian yang dilakukan oleh Puspitasari (2009), mengungkapkan bahwa suku bunga SBI tidak berpengaruh terhadap ROA.

Dalam perbankan, nilai tukar valas mempunyai pengaruh terhadap tingkat profitabilitas. Nilai tukar valas akan menentukan imbal hasil investasi riil. Mata uang yang menurun secara jelas akan mengurangi daya beli dari pendapatan dan keuntungan modal yang didapat dari jenis investasi apapun. Penurunan investasi ini akan mempengaruhi kegiatan operasional bank syariah. Sehingga setiap perubahan nilai tukar valas akan mempengaruhi pendapatan dan profit bank syariah (Sukirno, 2006:38). Penelitian oleh Rosanna (2007) mengatakan bahwa nilai tukar valas berpengaruh signifikan terhadap profitabilitas. Sedangkan, penelitian oleh Perdana (2009) terhadap bank umum menunjukkan hasil yang berbeda. Hasil penelitiannya 
menunjukkan bahwa nilai tukar valas tidak berpengaruh signifikan terhadap profitabilitas bank umum.

Jumlah uang beredar juga mempunyai pengaruh terhadap tingkat profitabilitas bank. Pada perbankan, pengaruh kenaikan jumlah uang beredar menyebabkan turunnya suku bunga. Penurunan suku bunga ini mengindikasikan bahwa tingkat investasi mengalami kenaikan. Dengan naiknya investasi, permintaan pembiayaan pada bank syariah juga akan meningkat. Sehingga pendapatan serta profit bank syariah juga akan ikut meningkat (Sukirno, 2006:283). Teori ini didukung oleh Nugroho (2008), hasil penelitiannya menyatakan bahwa jumlah uang beredar berpengaruh signifikan terhadap profitabilitas bank umum. Perdana (2009) mengungkapkan hal yang berbeda. Dari hasil penelitiannya tidak terdapat pengaruh signifikan antara jumlah uang beredar dengan besarnya dana yang dihimpun oleh bank umum. Semakin tinggi jumlah uang beredar maka dana yang dihimpun semakin kecil.

Dengan adanya fenomena pada bank syariah yang didukung dengan reaserch gap tersebut, maka peneliti ingin meneliti dan memfokuskan penelitian ini pada "Pengaruh Inflasi, Suku Bunga, Nilai Tukar Valas dan Jumlah Uang Beredar Terhadap Profitabilitas Pada Perbankan Syariah di Indonesia Periode 2005-2009”.

\section{KAJIAN PUSTAKA}

\section{Kinerja Keuangan Bank}

Penilaian kinerja keuangan bank dapat dimaksudkan untuk menilai keberhasilan manajemen di dalam mengelola suatu badan usaha. Berdasarkan Surat Edaran Bank Indonesia No.6/23/DPNP tanggal 31 Mei 2004 tentang Sistem Penilaian Tingkat Kesehatan Bank Umum, terdapat enam indikator yang digunakan untuk menilai kinerja bank, yaitu permodalan (capital), kualitas asset (asset quality), manajemen (management), rentabilitas (earnings), likuiditas (liquidity), dan sensitivitas terhadap risiko pasar (sensitivity to market risk).

Dalam penelitian ini digunakan profitabilitas dalam menilai kinerja keuangan bank. Profitabilitas (profitability) atau bisa juga disebut dengan rentabilitas adalah kemampuan suatu bank dalam memperoleh laba (Simorangkir, 2004:156). Penilaian kuantitatif profitabilitas bank tertuang dalam Surat Edaran Bank Indonesia No.6/23/DPNP tanggal 31 Mei 2004, terdapat delapan indikator yang digunakan untuk mengukur tingkat profitabilitas, yaitu: Return on asset, Return on equity, Net interest margin, Biaya operasional dibandingkan dengan pendapatan operasional, Perkembangan laba operasional, Komposisi portofolio aktiva produktif dan diversifikasi pendapatan, Penerapan prinsip akuntansi dalam pengakuan pendapatan, dan Prospek laba operasional

Dalam penelitian ini yang akan digunakan sebagai indikator profitabilitas adalah ROA. Penggunaan ROA ini didasarkan atas penelitian terdahulu oleh Setiawan (2009) dan Rosanna (2007). Penelitian tersebut menggunakan ROA untuk mengukur profitabilitas bank. Menurut Setiawan (2009), ROA penting bagi bank karena Bank Indonesia lebih mengutamakan nilai profitabilitas suatu bank yang 
diukur dengan asset yang dananya sebagian besar berasal dari dana simpanan masyarakat. Van Horne (2002:361) juga mengemukakan bahwa rasio yang digunakan umumnya dalam mengukur tingkat profitabilitas adalah ROA. Di samping itu, ROA merupakan metode pengukuran yang paling obyektif yang didasarkan pada data akuntansi yang tersedia dan besarnya ROA dapat mencerminkan hasil dari serangkaian kebijakan perusahaan terutama perbankan. ROA merupakan ukuran dari kinerja keuangan bank dalam memperoleh laba sebelum pajak, yang dihasilkan dari total asset (total aktiva) bank yang bersangkutan (Surat Edaran BI No.3/30/DPNP tanggal 14 Desember 2001).

Berdasarkan Surat Edaran No.9/24/DPBS tentang Sistem Penilaian Tingkat Kesehatan Perbankan Syariah, Bank Indonesia menetapkan ROA minimal sebesar $1.26 \%$ atau lebih besar dari $1.25 \%$ untuk menentukan ROA suatu bank yang sehat. Sehingga semakin besar ROA menunjukkan kinerja bank semakin baik, karena tingkat pengembalian (return) semakin besar (Husnan, 1992:215). ROA merupakan perbandingan antara laba sebelum pajak dengan total asset dalam suatu periode.

\section{Inflasi}

Inflasi adalah proses kenaikan harga-harga umum barang-barang secara terusmenerus (Nopirin, 2007:25). Kenaikan harga dari satu atau dua macam barang saja tidak dapat dikatakan sebagai inflasi kecuali kenaikan tersebut membawa dampak terhadap kenaikan harga sebagian besar barang-barang lain.

Sedangkan menurut Sukirno (2006:14), inflasi merupakan suatu proses kenaikan harga-harga yang berlaku dalam sesuatu perekonomian. Jadi, dari kesimpulan di atas inflasi merupakan kecenderungan dari harga-harga untuk naik secara umum dan terus-menerus.

Perhitungan inflasi yang digunakan dalam penelitian ini yaitu dengan menggunakan IHK. Penggunaan IHK untuk mengukur tingkat inflasi ini didasarkan atas penelitian terdahulu oleh Hassan dan Bashir (2002), Kunt dan Huizinga (2001), Vong dan Chan (2008), dan Aburime pada tahun 2005. Indeks ini menghitung ratarata perubahan harga dalam suatu periode, dari suatu kumpulan barang dan jasa yang dikonsumsi oleh penduduk atau rumah tangga dalam kurun waktu tertentu. Indeks ini merupakan salah satu indikator ekonomi yang secara umum dapat menggambarkan tingkat inflasi atau deflasi harga barang dan jasa. (http://www.bps.go.id, diakses tanggal 17 Mei 2011). Selain itu, indikator yang sering digunakan untuk mengukur tingkat inflasi adalah IHK. IHK ini juga digunakan oleh Badan Pusat Statistik dan Bank Indonesia sebagai indikator untuk mengukur laju inflasi di Indonesia.

Kelebihan lain digunakannya IHK ini antara lain adalah merupakan alat ukur yang paling tepat dalam mengukur tingkat kesejahteraan masyarakat karena IHK mengukur indeks biaya hidup konsumen. Seperti yang berlaku pada negara-negara lain institusi yang bertugas mengumpulkan data statistik selalu memfokuskan sebagian besar sumber dayanya untuk menghasilkan data IHK yang reliabel dibandingkan indeks harga lainnya, sehingga hasil pengukuran IHK selalu memiliki 
kualitas yang lebih baik dan selalu tersedia secara tepat waktu (http://www.bi.go.id, diakses tanggal 17 Mei 2011).

\section{Suku Bunga}

Menurut Siamat (2004:220), SBI adalah surat berharga dalam mata uang rupiah yang diterbitkan oleh Bank Indonesia sebagai pengakuan utang berjangka waktu pendek dan diperjualbelikan dengan diskonto. Suku Bunga SBI dijadikan variabel independen yang dapat mempengaruhi ROA didasarkan hubungannya dengan tingkat risiko bank yang bermuara pada profitabilitas bank atau ROA.

Menurut hasil penelitian yang dilakukan Karim Business Consulting (KBC), mengatakan bahwa sebagian besar nasabah bank syariah termasuk kelompok yang rasional, sehingga perubahan tingkat bunga pada bank konvensional akibat naiknya suku bunga SBI dan perubahan variabel moneter lainnya dapat menyebabkan nasabah menarik dananya dari bank syariah.

Pada kesempatan yang lain, Karim menyatakan bahwa kenaikan suku bunga diakuinya sangat berdampak terhadap profitabilitas perbankan syariah, selisih $0.5 \%$ saja nasabah bisa pindah ke bank konvensional. Perpindahan dana nasabah ke bank konvensional sangat wajar karena mustahil bagi hasil bisa bersing dengan suku bunga yang begitu tinggi. Dalam hal ini bank syariah dihadapkan kepada dua pilihan, menurunkan pricing atau menaikkan bagi hasil untuk nasabah (Republika, Nop.2005).

Bank syariah dan bank konvensional saling bersaing dalam hal penyaluran dana dan penghimpunan dana. Karim (2006:272) menyebutkan bahwa bank syariah akan menghadapi risiko pasar diantaranya risiko tingkat bunga dan risiko nilai bagi hasil bank syariah lain yang menjadi pesaing. Risiko tingkat bunga adalah risiko yang timbul sebagai akibat dari fluktuasi tingkat bunga, meskipun bank syariah tidak menetapkan tingkat bunga, baik dari sisi pendanaan maupun sisi pembiayaan. Hal ini disebabkan pasar yang dijangkau bank syariah tidak hanya untuk nasabah yang loyal penuh terhadap syariah. Apabila tingkat bagi hasil lebih menguntungkan dari pada tingkat bunga maka nasabah lebih tertarik menyimpan dananya di bank syariah, sebaliknya apabila tingkat bunga lebih menguntungkan dari pada bagi hasil maka nasabah yang tidak loyal akan memindahkan dananya ke bank konvensional, dalam hal ini bank konvensional berperan sebagai indirect competitor market rate.

Dalam menentukan tingkat bagi hasil baik dalam pendanaan maupun pembiayaan, bank syariah masih mengacu kepada tingkat suku bunga umum sebagai equivalent rate atau masih dijadikan benchmark dalam penentuan margin bagi hasil (profit sharing). Meningkatnya suku bunga pada bank konvensional mengakibatkan nasabah akan memindahkan dananya ke bank konvensional. Naiknya suku bunga bank konvensional berakibat langsung terhadap sumber dana pihak ketiga bank syariah. Penurunan DPK pada bank syariah akibat pemindahan dana tersebut tentunya sangat mempengaruhi kegiatan operasional bank syariah dalam hal pembiayaan dan penyaluran dana. Bila hal tersebut terjadi, maka pendapatan dan profit bank akan menurun (Karim, 2002). 
Fenomena pengalihan dana akibat kenaikan tingkat bunga telah diwaspadai oleh para banker syariah pada pertengahan 2003, sebagaimana yang diungkapkan oleh Senior Vice President Syariah Banking Group Head Bank Niaga Syariah pada tabloid ekonomi Kontan No.1, Tahun X, 3 Oktober 2003, Halaman 20. Sebagai berikut:

Sebelum bunga SBI dan penjaminan dinaikkan, imbas hasil nasabah bisa mencapai 8,5\% lebih tinggi dari bunga bank konvensional hanya sekitar 7\%, namun setelah dinaikkan, deposito konvensional dengan pokok di atas 500.000 juta sudah bisa mendapat bunga 10\%, sehingga kecenderungan bunga bank tersebut mengakibatkan imbal hasil yang diberikan perbankan syariah menjadi kurang menarik (Tn, 2003:20).

Suku bunga yang digunakan dalam penelitian ini adalah suku bunga SBI dalam jangka waktu 30 hari atau 1 bulan. Penggunaan suku bunga SBI jangka waktu 1 bulan ini didasarkan atas penelitian terdahulu oleh Rosanna (2007), Puspitasari (2009), dan Perdana (2009). Selain itu, suku bunga SBI jangka waktu 1 bulan lebih dapat menggambarkan kebijakan moneter yang dilakukan Bank Indonesia setiap bulannya, dan tercermin setiap kondisi ekonomi makro di Indonesia beserta perubahannya setiap bulan, jika dibandingkan dengan suku bunga SBI jangka waktu 3 bulan.

Menurut Setiawan (2009), kelebihan lain digunakannya suku bunga SBI, yaitu: (a) SBI dipakai sebagai alat konstraksi moneter, artinya berpengaruh pada berkurangnya jumlah uang beredar dan juga sebagai alat ekspansi moneter bila jumlah uang beredar cukup besar, (b) SBI telah menjadi suatu wahana penting dalam sektor keuangan dewasa ini, terutama dalam peranannya sebagai patokan dalam pasar uang atau pinjam meminjam jangka pendek antar bank, (c) SBI berfungsi sebagai branchmark bagi kestabilan tingkat bunga pada dunia perbankan termasuk tingkat bagi hasil bagi perbankan syariah, (d) Bagi Bank Indonesia, SBI merupakan instrumen pengendali moneter, yaitu sebagai alternatif bagi perbankan dalam pemeliharaan secondary reserves dan menanamkan dana yang bersifat sementara, (e) menurunkan dan menekan tingkat inflasi.

\section{Nilai Tukar Valas}

Menurut Sukirno (2006:37) nilai tukar valuta asing adalah suatu nilai yang menunjukkan jumlah mata uang dalam negeri yang diperlukan untuk mendapat satu unit mata uang asing. Sedangkan menurut Hasibuan (2005:14), nilai tukar valuta asing adalah perbandingan nilai tukar mata uang suatu negara dengan mata uang negara asing atau perbandingan nilai tukar valuta antar negara. Jadi, dari kesimpulan di atas nilai tukar valuta asing adalah nilai mata uang suatu negara dinyatakan dalam nilai mata uang negara lain.

Nilai tukar valas yang digunakan dalam penelitian ini adalah kurs tengah US\$. Penggunaan kurs tengah US\$ ini didasarkan atas penelitian terdahulu oleh Rosanna 
(2007), Nugroho (2008), dan Perdana (2009). Salah satu kelebihan digunakannya kurs tengah, yaitu kurs ini ditetapkan oleh Bank Indonesia untuk memelihara integritas dan stabilitas sistem keuangan dan perekonomian nasional, serta stabilitas nilai tukar.

Untuk mencapai stabilitas nilai tukar perlu dilakukan pengaturan dalam pengelolaan risiko transaksi valuta asing yang dilakukan oleh perbankan. Salah satu faktor penting dalam pengelolaan risiko transaksi valuta asing perbankan adalah besaran posisi devisa neto yang diperkenankan dimiliki oleh perbankan. Jadi kurs ini digunakan oleh bank untuk menyusun laporan posisi devisa neto. Hal ini dijelaskan dalam Peraturan Bank Indonesia No.6/20/PBI/2004 tentang Posisi Devisa Neto Bank Umum.

Nilai tukar valas atau lazim juga disebut kurs valuta asing dalam berbagai transaksi ataupun jual beli valuta asing, dikenal ada empat jenis yakni (Thobarry, 2009): Selling Rate (kurs jual), Middle Rate (kurs tengah), Buying Rate (kurs beli), Flat Rate (kurs flat). Menurut Madura (2006:219) nilai tukar dapat dibedakan menjadi 4 sistem, yaitu: Sistem tetap (fixed), Sistem mengambang bebas (freely floating), Sistem mengambang terkendali (managed floating), Sistem terikat (pegged)

\section{Jumlah Uang Beredar}

Sukirno (2006:281) membedakan uang beredar menjadi dua pengertian, yaitu:

a. Dalam pengertian yang sempit uang beredar adalah mata uang dalam peredaran ditambah dengan uang giral yang dimiliki oleh perseorangan-perseorangan, perusahaan-perusahaan, dan badan-badan pemerintah. M1 (narrow money/transaction money) terdiri dari uang kartal (currency) dan uang giral (demand deposit). Uang kartal adalah uang kertas dan uang logam yang beredar di masyarakat atau uang dalam bentuk fisik. Sedangkan uang giral didefinisikan sebagai saldo rekening koran atau giro yang dimiliki oleh masyarakat pada bank.

b. Dalam pengertian luas uang beredar meliputi mata uang dalam peredaran, uang giral dan uang kuasi. Uang kuasi terdiri dari deposito berjangka, tabungan, dan rekening (tabungan) valuta asing milik swasta domestik. Uang beredar dalam pengertian luas ini dinamakan juga sebagai likuiditas perekonomian M2.

Jumlah uang beredar yang digunakan dalam penelitian ini adalah perubahan jumlah uang beredar dalam arti luas (M2).

Penggunaan jumlah uang beredar dalam arti luas ini didasarkan atas penelitian terdahulu oleh Nugroho (2008), dan Perdana (2009). Dalam pengertian M1 yang dicerminkan hanyalah jumlah uang yang dapat digunakan untuk melancarkan jalannya transaksi-transaksi perdagangan. Dan belum sepenuhnya menggambarkan jumlah uang yang dapat digunakan untuk membeli barang dan jasa yang tersedia dalam masyarakat. Kemampuan masyarakat untuk membeli barang dan jasa adalah lebih dicerminkan oleh M2 (Sukirno, 2006:283).

Selain itu, perkembangan M2 mencerminkan atau seiring dengan perkembangan ekonomi suatu negara. Apabila perekonomian semakin maju, komposisi M1 dalam peredaran uang semakin kecil, sebab penggunaan uang kuasi 
semakin besar. Bahkan pada perekonomian yang semakin maju banyak transaksi yang dilakukan melalui bank. Dengan meningkatnya M2 secara langsung maupun tidak langsung telah mencerminkan perekonomian yang semakin makmur. Hal ini disebabkan karena masyarakat hanya dapat menyimpan uangnya dalam bentuk tabungan deposito berjangka di saat pendapatannya lebih besar dari tingkat konsumsinya.

\section{METODE PENELITIAN}

Penelitian ini bertujuan untuk menguji hipotesis, yaitu pengaruh variabel independen yang terdiri dari inflasi, suku bunga, nilai tukar valas dan jumlah uang beredar terhadap variabel dependen yaitu ROA. Untuk analisis data dilakukan secara kuantitatif dengan menggunakan regresi linier berganda.

Metode analisis data yang digunakan dalam penelitian ini adalah analisis regresi berganda (multiple linier regression). Regresi berganda berguna untuk meramalkan pengaruh dua variabel prediktor atau lebih terhadap satu variabel kriterium atau untuk membuktikan ada atau tidaknya hubungan fungsional antara dua buah variabel bebas (X) atau lebih dengan sebuah variabel terikat (Y) (Ashari dan Santosa, 2005:144). Formulasi persamaan regresi berganda sendiri adalah sebagai berikut:

$Y=a+b_{1} X_{1}+b_{2} X_{2}+b_{3} X_{3}+b_{4} X_{4}+e$

Di mana:

$\mathrm{Y}=\mathrm{ROA}$

$\mathrm{a}=$ Konstanta

$\mathrm{b}=$ Koefisien regresi

$\mathrm{X}_{1}=$ Inflasi

$\mathrm{X}_{2}=$ Suku Bunga

$\mathrm{X}_{3}=$ Nilai Tukar Valas

$\mathrm{X}_{4}=$ Jumlah Uang Beredar

$\mathrm{e}=$ Error

Adapun populasi dalam penelitian ini adalah seluruh bank umum syariah dan unit usaha syariah yang ada di Indonesia sampai dengan tahun 2009. Jumlah keseluruhan populasi yang ada adalah 31, terdiri dari 6 bank umum syariah dan 25 unit usaha syariah. Metode sampling yang digunakan dalam penelitian ini adalah non probability sampling dengan teknik pengambilan sampel purposive sampling.

Teknik ini ditentukan untuk memilih anggota sampel secara khusus berdasarkan tujuan penelitian dan kesesuaian kriteria-kriteria yang telah ditetapkan oleh peneliti (Cooper dan Schindler, 2006:84). Penulis menggunakan sampling ini karena dalam populasi yang ada tidak semua individu mempunyai kesempatan yang sama menjadi anggota sampling. 
Adapun kriteria dipilihnya anggota populasi menjadi sampel dalam penelitian ini adalah bank yang tidak mempublikasikan laporan keuangan berturut-turut selama periode 2005-2009 ditemukan sebanyak 21 bank yang layak dijadikan sampel.

\section{Variabel Penelitian dan Definisi Operasional Variabel}

Variabel dapat diartikan sebagai segala sesuatu yang akan menjadi objek pengamatan penelitian (Arikunto, 2006:118). Ada dua variabel yang digunakan dalam penelitian ini, yaitu variabel independen atau variabel bebas yang selanjutnya dinyatakan dengan simbol $\mathrm{X}$ dan variabel dependen atau variabel terikat yang selanjutnya dinyatakan dengan simbol Y. Berikut ini akan dijelaskan mengenai identifikasi variabel-variabel dalam penelitian ini beserta pengukurannya.

1. Variabel Independen (X)

Variabel independen merupakan variabel yang mempengaruhi variabel dependen (Arikunto, 2006:119). Variabel independen yang digunakan dalam penelitian ini meliputi:

a. Variabel Inflasi $\left(\mathrm{X}_{1}\right)$

Inflasi dalam penelitian ini ditunjukkan dalam indeks harga konsumen.

b. Variabel Suku Bunga $\left(\mathrm{X}_{2}\right)$

Suku bunga yang digunakan dalam penelitian ini adalah suku bunga Sertifikat Bank Indonesia dalam jangka waktu 30 hari atau 1 bulan.

c. Variabel Nilai Tukar Valas $\left(\mathrm{X}_{3}\right)$

Nilai tukar valas yang digunakan dalam penelitian ini adalah perubahan kurs tengah US\$.

$$
\mathrm{X}_{3 \mathrm{t}}=\frac{\mathrm{K}_{\mathrm{t}}-\mathrm{K}_{\mathrm{t}-1}}{\mathrm{~K}_{\mathrm{t}-1}} \times 100 \%
$$

d. Variabel Jumlah Uang Beredar $\left(\mathrm{X}_{4}\right)$

Jumlah uang beredar yang digunakan dalam penelitian ini adalah perubahan jumlah uang beredar dalam arti luas atau M2

$$
\mathrm{X} 4 \mathrm{t}=\frac{\mathrm{M} 2_{\mathrm{t}}-\mathrm{M} 2_{\mathrm{t}-1}}{\mathrm{M} 2_{\mathrm{t}-1}} \times 100 \%
$$

2. Variabel Dependen (Y)

Rumus yang digunakan untuk mencari ROA adalah sebagai berikut:

$$
\text { ROA }=\frac{\text { Laba Sebelum Pajak }}{\text { Total Assets }} \times 100 \%
$$




\section{HASIL DAN PEMBAHASAN}

\section{Pengaruh Inflasi, Suku Bunga, Nilai Tukar Valas dan Jumlah Uang Beredar Secara Bersama-Sama Terhadap ROA}

Berdasarkan analisa data di atas diketahui bahwa secara simultan inflasi, suku bunga, nilai tukar valas dan jumlah uang beredar berpengaruh signifikan terhadap ROA perbankan syariah tahun 2005-2009. Hasil penelitian ini sesuai dengan teori yang dikemukakan oleh Sukirno (2006:26), yang menyatakan bahwa faktor-faktor ekonomi makro seperti inflasi, nilai tukar valas, jumlah uang beredar dan suku bunga berpengaruh terhadap profitabilitas bank.

Berdasarkan Laporan Perkembangan Perbankan Syariah (BI, 2008), ketika krisis ekonomi global tahun 2008 melanda Indonesia, yang ditandai dengan naiknya inflasi, tingginya suku bunga, kurs yang terdepresiasi dan menurunnya jumlah uang beredar, menyebabkan profitabilitas perbankan syariah mengalami penurunan. Secara keseluruhan dapat dilihat bahwa industri perbankan syariah tahun 2008 cenderung terjadi penurunan laju pertumbuhan kegiatan usaha dan tingkat profitabilitas. Selain itu, perkembangan tingkat kesehatan bank juga mengalami penurunan dibandingkan dengan tahun 2007.

Dengan adanya beberapa kondisi makro tersebut menyebabkan terjadinya perlambatan pada perbankan khususnya perlambatan pertumbuhan pembiayaan. Penurunan laju pertumbuhan pembiayaan perbankan syariah relatif signifikan yaitu sebesar 14\% dari tumbuh 36,7\% tahun 2007 menjadi 22,8\% tahun 2008. Sementara itu penurunan laju pertumbuhan asset sebesar 2,2\% dari 35,6\% menjadi $33,4 \%$ tahun 2008.

Di triwulan ke empat tahun 2008, kondisi ROA industri perbankan syariah mengalami penurunan di mana ROA mencapai $1,42 \%$. Penurunan ROA tersebut antara lain disebabkan karena adanya penurunan net operation margin akibat menurunnya pendapatan atas pembiayaan yang dilakukan perbankan syariah di tahun 2008, dengan pendapatan dari pembiayaan murabahah dan musyarakah sebagai kontributor terbesar (Statistik Perbankan Syariah, BI:2008).

Kondisi perbankan tersebut terus berlanjut selama tahun 2009, pertumbuhan asset industri perbankan syariah cenderung mengalami perlambatan. Setelah mengalami penurunan pada triwulan IV tahun 2008, pertumbuhan jumlah pembiayaan dan profitabilitas perbankan syariah sempat mengalami peningkatan pada triwulan I dan II tahun 2009. Namun kondisi tersebut kembali menunjukkan penurunan pada triwulan IV tahun 2009.

Hal tersebut antara lain dipengaruhi oleh kelesuan ekonomi nasional, belum pulihnya daya beli masyarakat, dan biaya ekonomi yang tinggi yang berdampak pada adanya pembatasan ekspansi usaha dan pengurangan konsumsi. Kondisi tersebut merupakan cerminan dari aktifitas sektor riil yang masih dalam masa pemulihan setelah terkena dampak krisis keuangan global yang bermula dari Amerika Serikat dan ketatnya kredit atau likuiditas global. Sehingga perbankan syariah lebih berhatihati dalam penyaluran pembiayaan. Kehati-hatian ini disebabkan perbankan syariah 
belum yakin sepenuhnya akan kinerja beberapa sektor ekonomi akibat krisis ekonomi global pada akhir tahun 2008 (Statistik Perbankan Syariah, BI:2008).

Dari pembahasan di atas dapat disimpulkan bahwa variabel ekonomi makro yang terdiri dari inflasi, suku bunga, nilai tukar valas dan jumlah uang beredar mempunyai perubahan yang berarti sehingga pelaku perbankan cenderung untuk meresponnya secara keseluruhan sebagai variabel yang mempengaruhi pendapatan dan profit bank di masa yang akan datang.

\section{Pengaruh Inflasi, Suku Bunga, Nilai Tukar Valas dan Jumlah Uang Beredar Secara Parsial Terhadap ROA}

Penelitian ini menunjukkan bahwa dari empat variabel indikator ekonomi makro yang diteliti, yaitu inflasi, suku bunga, nilai tukar valas dan jumlah uang beredar, hanya inflasi yang tidak berpengaruh signifikan terhadap ROA. Berikut penjabaran dari masing-masing pengaruh dan hubungan antara variabel independen dengan variabel dependen:

\section{Pengaruh Inflasi Terhadap ROA}

Selama periode penelitian tingkat inflasi tidak berpengaruh terhadap ROA perbankan syariah. Hasil penelitian ini didukung oleh penelitian Kunt dan Huizinga pada tahun 2001. Kunt menjelaskan bahwa inflasi tidak berpengaruh terhadap profitabilitas bank umum. Selain itu, Aburime pada tahun 2005 juga mengatakan bahwa inflasi tidak mempunyai pengaruh dengan profitabilitas bank umum di Nigeria. Rosanna (2007) juga menyatakan bahwa inflasi tidak berpengaruh signifikan terhadap profitabilitas perbankan syariah.

Rosanna (2007) mengatakan bahwa pada saat inflasi tinggi maka masyarakat lebih percaya terhadap perbankan syariah dibandingkan dengan perbankan konvensional. Kepercayaan masyarakat tersebut juga dimungkinkan karena adanya pengalaman historis pada saat terjadi krisis ekonomi pada tahun 1997, di mana pada masa tersebut tingkat inflasi di Indonesia sangat tinggi dan akhirnya mengakibatkan banyak bank konvensional yang mengalami kebangkrutan akibat menerapkan tingkat bunga yang terlalu tinggi untuk mengimbangi laju inflasi serta untuk menarik nasabah agar tetap menempatkan dananya sehingga mengakibatkan terjadinya negative spread dan pada akhirnya bank tersebut tidak dapat mengembalikan dana masyarakat yang telah disimpan beserta bunganya.

Di saat krisis moneter yang terjadi pada tahun 1998 telah menenggelamkan bank-bank konvensional dan banyak yang dilikuidasi karena kegagalan sistem bunganya. Sementara perbankan yang menerapkan sistem syariah dapat tetap berdiri dan mampu bertahan. Hal ini dapat dibuktikan dari keberhasilan bank Muamalat Indonesia melewati krisis yang terjadi pada tahun 1998 dengan menunjukkan kinerja yang semakin meningkat dan tidak menerima sama sekali bantuan dari pemerintah bahkan mampu memperoleh laba Rp. 300 milliar lebih (Statistik Perbankan Syariah, BI:2011). 
Keberhasilan perbankan syariah dalam melewati krisis tahun 1998 juga terjadi pada krisis global tahun 2008. Pada saat tahun 2008 tingkat inflasi mengalami kenaikan sebesar $11.06 \%$, tetapi tingkat kepercayaan masyarakat terhadap perbankan syariah tetap naik sebesar $12.5 \%$. Selain itu, dikeluarkannya Fatwa MUI pada tanggal 16 November 2003 yang menjelaskan bahwa bunga bank adalah riba dan berstatus haram telah meningkatkan kepercayaan masyarakat terhadap perbankan syariah.

Menurut Laporan Perkembangan Perbankan Syariah (BI:2011) dampak guncangan krisis keuangan global tahun 2008 terhadap industri perbankan syariah di Indonesia tidak terlalu berpengaruh. Karena pembiayaan perbankan syariah yang masih lebih diarahkan kepada aktivitas perekonomian domestik, sehingga belum memiliki tingkat integrasi yang tinggi dengan sistem keuangan global dan belum memiliki tingkat transaksi yang tinggi, adalah dua faktor yang dinilai telah menyelamatkan bank syariah dari dampak langsung guncangan sistem keuangan global. Padahal pada tahun 2008 tingkat inflasi mengalami kenaikan sebesar $11.06 \%$.

Pembiayaan untuk kebutuhan modal kerja masih merupakan kelompok pembiayaan yang dominan. Hal ini mengingat kebutuhan pembiayaan modal kerja masih merupakan kebutuhan utama nasabah pembiayaan perbankan syariah yang didominasi oleh UKM. Sementara itu, kelompok pembiayaan konsumsi juga menunjukkan peningkatan sebagai dampak pengembangan berbagai produk pembiayaan konsumsi seperti pembiayaan pembelian kendaraan bermotor dan properti berbasis murabahah.

Menurut Arsitektur Perbankan Indonesia (2008), dengan posisi perbankan syariah sebagai beyond banking, yaitu perbankan yang menyediakan produk dan jasa keuangan yang lebih beragam serta didukung oleh skema keuangan yang lebih bervariasi, kita yakin bahwa di masa-masa mendatang akan semakin tinggi minat masyarakat Indonesia untuk menggunakan bank syariah. Dan pada gilirannya hal tersebut akan meningkatkan signifikansi peran bank syariah dalam mendukung stabilitas sistem keuangan nasional, bersama-sama secara sinergis dengan bank konvensional dalam kerangka dual banking system (sistem perbankan ganda). Sehingga dapat disimpulkan bahwa selama periode penelitian di Indonesia tingkat inflasi tidak begitu berpengaruh terhadap profitabilitas perbankan syariah di Indonesia.

\section{Pengaruh Suku Bunga Terhadap ROA}

Dalam penelitian ini, suku bunga SBI mempengaruhi tingkat ROA perbankan syariah. Hasil penelitian ini sesuai dengan teori Karim (2006:272), yaitu suku bunga SBI berpengaruh terhadap profitabilitas bank syariah. Dalam menentukan tingkat bagi hasil baik dalam pendanaan maupun pembiayaan, bank syariah masih mengacu kepada tingkat suku bunga umum sebagai equivalent rate atau masih dijadikan benchmark dalam penentuan margin bagi hasil (profit sharing).

Meningkatnya suku bunga pada bank konvensional mengakibatkan nasabah akan memindahkan dananya ke bank konvensional. Naiknya suku bunga bank konvensional berakibat langsung terhadap sumber dana pihak ketiga bank syariah. 
Penurunan DPK pada bank syariah akibat pemindahan dana tersebut tentunya sangat mempengaruhi kegiatan operasional bank syariah dalam hal pembiayaan dan penyaluran dana. Bila hal tersebut terjadi, maka pendapatan dan profit bank akan menurun (Karim, 2002).

Berdasarkan hasil regresi linier berganda, penelitian ini menunjukkan bahwa setiap kenaikan suku bunga SBI akan mengakibatkan kenaikan ROA, dan sebaliknya setiap penurunan tingkat suku bunga SBI akan menurunkan ROA. Hasil penelitian ini sesuai dengan Rosanna (2007). Rosanna menyatakan bahwa suku bunga SBI berpengaruh signifikan terhadap profitabilitas perbankan syariah. Tidak semua nasabah bank syariah termasuk kelompok yang rasional, dan nasabah yang loyalis syariah tidak akan terpengaruh oleh fluktuasi tingkat suku bunga di bank konvensional.

Adanya Fatwa pada tanggal 16 November 2003 yang menjelaskan bahwa bunga bank adalah riba dan berstatus haram telah memberikan harapan besar bagi perkembangan perbankan syariah. Selain itu, mayoritas masyarakat Indonesia beragam Islam. Dengan jumlah penduduk lebih dari 220 juta saat ini, lebih dari $80 \%$ nya beragama Islam. Seperti yang diungkapkan Huntington dalam bukunya The Clash and the Remaking of the World Order, telah terjadi trend global, yaitu adanya peningkatan kesadaran atas identitas etnis, kultural, dan agama.

Sebagai bagian dari masyarakat global, jika fenomena kesadaran akan identitas agama ini benar, maka akan terjadi kecenderungan bahwa masyarakat Indonesia yang beragama Islam akan berusaha menjalankan syariat Islam secara konsekuen, termasuk dalam bermuamalat. Dalam menyimpan dan meminjam dana, tentunya akan berusaha untuk menggunakan intermediasi keuangan yang sesuai dengan akidah Islam. Dengan demikian dapat disimpulkan bahwa potensi pasar perbankan syariah di Indonesia sangat besar. Adanya kedua faktor di atas dapat meningkatkan nasabah yang loyalis terhadap perbankan syariah (Rosanna, 2007).

Berdasarkan data dari Statistik Ekonomi Moneter Indonesia (2011), pada tahun 2005 suku bunga SBI mengalami kenaikan sebesar 12.75\%. Tetapi, kenaikan tersebut diikuti dengan naiknya volume simpanan masyarakat dan pembiayaan pada perbankan syariah. Selain kenaikan DPK perbankan syariah, kenaikan suku bunga SBI juga diikuti dengan meningkatnya pembiayaan pada perbankan syariah. Hal ini berakibat dengan meningkatnya profitabilitas perbankan syariah sebesar Rp. 238,6 miliar, meningkat sebesar Rp. 76,3 miliar dari tahun sebelumnya (Laporan Perkembangan Perbankan Syariah, BI:2005).

\section{Pengaruh Nilai Tukar Valas Terhadap ROA}

Dalam penelitian ini, nilai tukar valas mempengaruhi tingkat ROA perbankan syariah. Hasil penelitian ini juga sesuai dengan penelitian oleh Rosanna (2007) yang mengatakan bahwa nilai tukar valas berpengaruh signifikan terhadap profitabilitas perbankan syariah. Nilai tukar valas akan menentukan imbal hasil investasi riil. Mata uang yang menurun secara jelas akan mengurangi daya beli dari pendapatan dan keuntungan modal yang didapat dari jenis investasi apapun. Penurunan investasi ini 
akan mempengaruhi kegiatan operasional bank. Dengan turunnya investasi, permintaan pembiayaan pada bank syariah juga akan menurun dan selanjutnya akan berpengaruh terhadap rasio keuangan bank, salah satunya rasio profitabilitas yang diwakili oleh ROA (Sukirno, 2006:38). Penelitian ini juga menunjukkan, setiap kenaikan nilai tukar valas akan mengakibatkan kenaikan ROA, dan sebaliknya setiap penurunan nilai tukar valas akan menurunkan ROA.

Berdasarkan data dari Statistik Ekonomi Moneter Indonesia (2011), pada tahun 2006 terjadi perubahan kurs tengah sebesar -8.24\%. Perubahan yang negatif menunjukkan rupiah mengalami apresiasi terhadap dollar Amerika Serikat. Apresiasi tersebut diikuti dengan naiknya profitabilitas perbankan syariah sebesar $4.34 \%$. Berdasarkan Laporan Perekonomian Indonesia (BI, 2007), pada tahun 2008 terjadi depresiasi kurs terbesar selama periode penelitian yaitu sebesar $16.25 \%$.

Dinamika nilai tukar rupiah selama tahun 2008 sangat dipengaruhi oleh perkembangan krisis keuangan global, gejolak harga komoditas, dan perlambatan ekonomi dunia yang memicu memburuknya persepsi investor dan ekspektasi pelaku pasar. Gejolak eksternal tersebut menyebabkan perkembangan nilai tukar rupiah selama tahun 2008 sangat berfluktuasi, terutama sejak awal triwulan IV-2008. Namun demikian, dampak krisis keuangan global yang semakin luas memicu pelepasan aset oleh investor dalam jumlah yang signifikan sehingga menimbulkan tekanan yang kuat terhadap nilai tukar rupiah pada triwulan IV-2008. Depresiasi tersebut diikuti dengan penurunan tingkat profitabilitas perbankan syariah sebesar $3.12 \%$.

Penurunan profitabilitas perbankan syariah ini disebabkan karena pertumbuhan aset dan DPK perbankan syariah mengalami perlambatan sebagai dampak dari menurunnya kondisi likuiditas bank dan melambatnya aktivitas sektor riil yang mulai terimbas krisis keuangan global. Hal ini dapat dilihat pada Tabel 2.

Tabel 2. Komposisi DPK Perbankan Syariah

\begin{tabular}{lcrcc}
\hline \multicolumn{1}{c}{ Keterangan } & \multicolumn{2}{c}{ Jumlah (milliar Rp) } & \multicolumn{2}{c}{ Pertumbuhan (\%) } \\
\hline & $\mathbf{2 0 0 7}$ & $\mathbf{2 0 0 8}$ & $\mathbf{2 0 0 7}$ & $\mathbf{2 0 0 8}$ \\
Giro Wadiah & 4.238 & 3.75 & 9.8 & 13.0 \\
Tabungan Mudharabah & 12.471 & 9.454 & 47.0 & 31.9 \\
Deposito Mudharabah & 20.143 & 14.807 & 36.8 & 36.0 \\
Total DPK & $\mathbf{3 6 . 8 5 2}$ & $\mathbf{2 8 . 0 1 2}$ & $\mathbf{3 5 . 5}$ & $\mathbf{3 1 . 6}$ \\
\hline
\end{tabular}

Sumber: Bank Indonesia (2008)

Selain penurunan DPK yang dihimpun oleh perbankan syariah, depresiasi nilai tukar valas juga menyebabkan penyaluran pembiayaan yang diberikan oleh bank syariah juga mengalami penurunan selama tahun 2008. Hal ini dapat dilihat pada Tabel 3. 
Tabel 3. Perkembangan Jenis-Jenis Pembiayaan Perbankan Syariah

\begin{tabular}{lcccr}
\hline \multicolumn{1}{c}{ Keterangan } & \multicolumn{2}{c}{ Jumlah (milliar Rp) } & \multicolumn{2}{c}{ Pertumbuhan (\%) } \\
\hline & $\mathbf{2 0 0 7}$ & $\mathbf{2 0 0 8}$ & $\mathbf{2 0 0 7}$ & $\mathbf{2 0 0 8}$ \\
Musyarakah & 7.411 & 4.406 & 88,7 & 68,2 \\
Mudharabah & 6.205 & 5.578 & 37,3 & 11,2 \\
Piutang Mudharabah & 22.486 & 16.553 & 31,1 & 35,8 \\
Piutang Istishna & 369 & 351 & 4,2 & 5,1 \\
Piutang Qardh & 959 & 540 & 116,0 & 77,5 \\
Ijarah & 765 & 516 & $-38,3$ & 48,3 \\
Total & $\mathbf{3 8 . 1 9 5}$ & $\mathbf{2 7 . 9 4 4}$ & $\mathbf{3 6 , 7}$ & $\mathbf{3 2 , 7}$ \\
\hline
\end{tabular}

Sumber: Bank Indonesia (2008)

\section{Pengaruh Jumlah Uang Beredar Terhadap ROA}

Dalam penelitian ini, jumlah uang beredar mempengaruhi ROA perbankan syariah. Hal ini sesuai dengan Sukirno (2006:283), apabila jumlah uang beredar naik, maka suku bunga akan turun. Penurunan suku bunga akan menambah investasi dalam perekonomian. Pertambahan investasi ini akan mempengaruhi kegiatan operasional bank syariah. Dengan naiknya investasi, permintaan pembiayaan pada bank syariah juga akan meningkat. Dan untuk selanjutnya akan berpengaruh terhadap rasio keuangan bank, salah satunya rasio profitabilitas yang diwakili oleh ROA.

Penelitian ini juga menunjukkan, setiap kenaikan jumlah uang beredar akan mengakibatkan kenaikan ROA, dan sebaliknya setiap penurunan jumlah uang beredar akan menurunkan ROA. Hasil penelitian ini juga didukung oleh Nugroho (2008), hasil penelitiannya menyatakan bahwa jumlah uang beredar berpengaruh signifikan terhadap profitabilitas bank umum.

Di Indonesia, khususnya pada periode penelitian ini jumlah uang beredar sangat mempengaruhi profitabilitas perbankan syariah di Indonesia. Berdasarkan Statistik Ekonomi Keuangan Indonesia (2011), pada tahun 2007 terjadi peningkatan jumlah uang beredar sebesar 19.32\%. Peningkatan jumlah uang beredar ini disebabkan karena membaiknya daya beli masyarakat dan tingginya permintaan dunia terhadap produk ekspor Indonesia, menjadi faktor utama pendorong pertumbuhan ekonomi pada tahun 2007. Hal ini tercermin pada pertumbuhan konsumsi swasta yang terus tumbuh dengan tren yang meningkat sejak awal tahun menjadi $5,0 \%$ pada tahun 2007, dibandingkan dengan tahun sebelumnya sebesar 3,2\%.

Pulihnya daya beli masyarakat tersebut dirasakan oleh hampir seluruh kalangan masyarakat. Menurut Laporan Perekonomian Indonesia (BI, 2007), investasi juga tumbuh lebih tinggi dibandingkan dengan tahun sebelumnya. Pada tahun 2007, investasi tumbuh sebesar 9,2\% meningkat dibandingkan dengan 2,5\% pada tahun 2006. Peningkatan investasi ini tercermin pada naiknya pembiayaan yang disalurkan oleh perbankan syariah. Dan untuk selanjutnya akan diikuti dengan naiknya profitabilitas perbankan syariah sebesar $4.89 \%$. 
Tabel 4. Perkembangan Jenis-Jenis Pembiayaan Perbankan Syariah

\begin{tabular}{lcr}
\hline & Keterangan & \multicolumn{2}{c}{$\begin{array}{c}\text { Jumlah } \\
\text { (milliar Rp) }\end{array}$} \\
\cline { 2 - 3 } Musyarakah & $\mathbf{2 0 0 6}$ & $\mathbf{2 0 0 7}$ \\
Mudharabah & 2.335 & 7.411 \\
Piutang Mudharabah & 4.062 & 6.205 \\
Piutang Istishna & 12.624 & 22.486 \\
Piutang Qardh & 337 & 369 \\
Ijarah & 250 & 959 \\
Total & 836 & 765 \\
\hline
\end{tabular}

Sumber: Bank Indonesia (2008)

Sedangkan tahun 2009 jumlah uang beredar mengalami penurunan yang cukup rendah, yaitu sebesar $14.92 \%$. Kondisi tersebut merupakan cerminan dari aktifitas sektor riil yang masih dalam masa pemulihan setelah terkena dampak krisis keuangan global yang bermula dari Amerika Serikat dan ketatnya kredit atau likuiditas global. Berdasarkan Statistik Perbankan Syariah (2009), menurunnya jumlah uang beredar ini berdampak pada pembiayaan yang disalurkan oleh perbankan syariah sebesar $1,3 \%$ dari tahun 2008 . Penurunan ini juga menyebabkan profitabilitas perbankan syariah turun sebesar $4.26 \%$.

\section{SIMPULAN}

Pada penelitian ini didapatkan hasil bahwa secara bersama-sama variabel inflasi, suku bunga, nilai tukar valas dan jumlah uang beredar mempunyai pengaruh yang signifikan terhadap ROA perbankan syariah di Indonesia. Hasil secara parsial suku bunga, nilai tukar valas dan jumlah uang beredar mempunyai pengaruh yang signifikan terhadap ROA. Sedangkan variabel inflasi mempunyai pengaruh yang tidak signifikan terhadap ROA perbankan syariah. Hal ini disebabkan, pada saat inflasi tinggi maka masyarakat lebih percaya terhadap perbankan syariah dibandingkan dengan perbankan konvensional. Dan pembiayaan perbankan syariah yang masih lebih diarahkan kepada aktivitas perekonomian domestik, 


\section{DAFTAR PUSTAKA}

Arikunto, Suharsimi. 2006. Prosedur Penelitian Suatu Pendekatan Praktik. Jakarta: Rineka Cipta.

Brigham, Eugene F and Joel F.Houston, 2006. Dasar-Dasar Manajemen Keuangan, alih bahasa Ali Akbar Yulianto, Buku satu, Edisi sepuluh, PT. Salemba Empat, Jakarta. Siamat (2004:220)

Cooper dan Schindler. 2006. Marketing Research. New York: The McGraw-Hill Companies, Inc.

Hasibuan, Malayu S.P. 2005. Manajemen Sumber Daya Manusia, Edisi Revisi. Bumi Aksara, Jakarta.

Hassan, Kabir M, dan Bashir, Abdel- Hameed M. 2002. Determinants of Islamic Banking Profitability. International Journal. ERF paper.

Kunt, Demirguc dan Huizinga, Harry . 2001. Determinants of Commercial Bank Interest Margin and Profitabilitas :some international Evidence. World Bank Economic Review 13, 379-408

Madura, Jeff. 2006. Keuangan Perusahaan Internasional, Edisi Kedelapan. Jakarta:Salemba Empat.

Marieskha, Poppy. 2009. Analisis Pengaruh PDRB, Suku Bunga, Dan Tingkat Inflasi Terhadap Simpanan Masyarakat Pada Bank-Bank Umum Di Sumatera Utara. Skripsi Universitas Sumatera Utara.

Nugroho, Heru . 2008. Analisis Pengaruh Inflasi, Suku Bunga, Kurs dan Jumlah Uang Beredar Terhadap Profitabilitas Perbankan (Studi pada Bank Umum Go Public yang Listed di Bursa Efek Indonesia Tahun 2002-2007. Thesis Magister Manajemen Universitas Diponegoro.

Peraturan Bank Indonesia No.6/20/PBI/2004 tentang Posisi Devisa Neto Bank Umum.

Perdana, Dian Putra . 2009. Pengaruh Suku Bunga Sertifikat Bank Indonesia, Kurs, Inflasi dan Jumlah Uang Beredar Terhadap Bank Umum Go Public di Bursa Efek Indonesia Periode 2006-2008. Thesis Universitas Gunadarma.

Puspitasari, Diana . 2009. Analisis Pengaruh CAR, NPL, PDN, NIM, BOPO, LDR, dan Suku Bunga SBI Terhadap ROA (Studi Pada Bank Devisa di Indonesia Periode 2003-2007. Tesis Magister Manajemen Universitas Diponegoro.

Rosanna, Rizky Dahlia. 2007. Pengaruh Inflasi, Nilai Tukar dan Suku Bunga SBI Terhadap Profitabilitas Perbankan Syariah di Indonesia Tahun 2002-2006. Thesis Universitas Islam Indonesia.

Simorangkir,O.P. 2004. Pengantar Lembaga Keuangan Bank dan Non Bank. Jakarta. Ghalia Indonesia.

Sukirno, Sadono, 2006. Ekonomi Pembangunan: Proses, Masalah, dan Dasar Kebijakan, Edisi Kedua, Jakarta: Penerbit Kencana Prenada Media Group.

Statistik Perbankan Syariah, BI:2011

Surat Edaran Bank Indonesia No.6/23/DPNP tanggal 31 Mei 2004 tentang Sistem Penilaian Tingkat Kesehatan Bank Umum. 
Surat Edaran No.9/24/DPBS tentang Sistem Penilaian Tingkat Kesehatan Perbankan Syariah

Nopirin, 2007, Ekonomi Moneter. Yogyakarta : BPFE-Yogyakarta.

Thobarry, Achmad Ath. 2009. Analisis Pengaruh Nilai Tukar, Suku Bunga, Laju Inflasi Dan Pertumbuhan Gdp Terhadap Indeks Harga Saham Sektor Properti (Kajian Empiris Pada Bursa Efek Indonesia Periode Pengamatan Tahun 20002008 ). Thesis Magister Manajemen Universitas Diponegoro

Van Horne, James C. 2002. Financial Management and Policy, 12th ed. New York: Prentice-Hall International Inc.

Vong, Anna P. I. dan Chan, Hoi Si. 2008. Determinants of Bank Profitability in Macao.

http://www.amcm.gov.mo/publication/quarterly/July2009/macaoprof_en.pdf. 